\title{
Karakteristik Total Padatan Tersuspensi (Total Suspended Solid) Dan Kekeruhan (Turbidity) Secara Vertikal Di Perairan Teluk Benoa, Bali
}

\author{
I Gede Hendrawan ${ }^{\mathrm{a} *}$, Devi Uniluha ${ }^{\mathrm{b}}$, I Putu Ranu Fajar Maharta ${ }^{\mathrm{a}}$ \\ ${ }^{a}$ Program Studi Ilmu Kelautan, Fakultas Kelautan dan Perikanan, Universitas Udayana,Kampus UNUD Bukit Jimbaran, Badung, Bali, Indonesia \\ ${ }^{b}$ Program Studi Manajemen Sumberdaya Perairan, Fakultas Kelautan dan Perikanan, Universitas Udayana,Kampus UNUD Bukit Jimbaran, Badung , \\ Bali, Indonesia \\ * Penulis koresponden. Tel.: +62-361-702-802 \\ Alamat e-mail: hendra_mil@yahoo.com
}

Diterima (received) 23 Februari 2016; disetujui (accepted) 8 Juni 2016; tersedia secara online (available online) 12 Juni 2016

\begin{abstract}
Benoa bay is one of estuary that located in the Southern part of Bali Island, and as a strategic tourism destination. The increased of the human activity has an important role to give an ecological pressure for the seawater ecosystem in the Benoa bay. Total suspended solid (TSS) and turbidity is one of the important indicators that could be determining the quality of the seawater. As the estuary, Benoa bay received fresh water from the river discharge that also potentially carries any material to the bay. In addition, port activity is also has an important role in contributing a various material to the Benoa bay. From this research, we found that the TSS concentration and the turbidity are higher in the surface water and also in the bottom layer. TSS concentration and the turbidity also varied from the bay mouth trough the line of vessel onto the inner of bay. TSS concentration and turbidity in the bay mouth has a smaller concentration rather than in the inner part of bay. TSS concentration and turbidity in the inner of bay could be caused by the port activity. In addition, seawater circulation is also has an importan factor to contributing the TSS concentration and the turbidity. Sea current would be erroted the seabottom and with the different shape of the topography could be increased the TSS and turbidity.
\end{abstract}

Keywords: TSS; Tubidity, Benoa; estuary

\begin{abstract}
Abstrak
Teluk Benoa merupakan perairan estuary yang terletak di Selatan Pulau Bali yang berada pada wilayah strategis pariwisata Bali. Peningkatan aktifitas masyarakat memiliki potensi besar dalam memberikan tekanan ekologi terhadap ekosistem perairan Teluk Benoa. Total padatan tersuspensi (total suspended solid/TSS) dan tingkat kekeruhan perairan merupakan salah satau indikator penting dalam menentukan kualitas suatu perairan. Sebagai perairan estuari, Teluk Benoa menerima masukan air dari aliran sungai yang berpotensi membawa berbagai macam material ke dalam teluk. Selain itu, aktifitas pelabuhan memiliki peran yang sangat penting dalam menyumbangkan berbagai macam materi ke dalam perairan. Dari penelitian yang telah dilakukan didapatkan konsentrasi TSS yang memiliki nilai cukup tinggi di bagian permukaan perairan dan pada kolom bagian dasar perairan,demikian halnya dengan tingkat kekeruhan memiliki karakteristik yang hampir sama. Konsentrasi TSS dan tingkat kekeruhan juga memiliki variasi yang berbeda dari luar teluk melalui jalur pelayaran kapal sampai dengan di dalam teluk. Konsentrasi TSS dan kekeruhan di sekitar mulut teluk memiliki nilai yang lebih kecil dibandingkan dengan di dalam teluk. Besarnya nilai TSS dan kekeruhan yang terdapat di dalam teluk dapat diakibatkan oleh aktifitas pelabuhan. Selain itu, arus laut yang memasuki wilayah teluk memiliki kontribusi dalam meningkatkan TSS dan kekeruhan disekitar alur pelayaran, dimana mekanisme tergerusnya dasar laut oleh arus dan perbedaan topography dasar laut memberikan kontribusi meningkatkan TSS dan kekeruhan pada wilayah perairan tersebut.
\end{abstract}

Kata Kunci: TSS; Kekeruhan; Benoa; estuari

\section{Pendahuluan}

Perairan Teluk Benoa merupakan salah satu wilayah perairan yang sangat penting bagi Pulau Bali, khususnya bagi Kabupaten Badung dan Kota Denpasar. Teluk Benoa menjadi muara bagi dua sungai besar yaitu Sungai Badung dan Sungai Mati, serta menjadi tempat tumbuhnya 1373,5 Ha tumbuhan mangrove (Kemenhut, 1993; Wiyanto dan Faiqoh, 2015) yang merupakan paru-paru kota Denpasar dan kabupaten Badung. Perairan Teluk Benoa merupakan perairan semi tertutup yang di pengaruhi oleh air tawar yang berasal dari aliran sungai, dan air laut yang berasal dari luar teluk. Kedalaman perairan dari garis pantai menuju mulut teluk berkisar antara 0-5 m, sementara perairan yang relatif dalam hanya berada pada wilayah perlintasan kapal laut yang dapat mencapai antara 5-15 m dari mulut teluk sampai dengan dermaga pelabuhan Benoa (Dishidros TNI AL, 2003).

Kualitas perairan adalah salah satu parameter yang sangat penting dalam menentukan tingkat kesehatan lingkungan bagi ekosistem di pesisir (Guang, 2009; Karr and Dudley, 1981). Salah satu parameter kualitas perairan yang penting adalah konsentrasi total padatan yang tersuspensi (total suspended solid/TSS) dan tingkat 
kekeruhan perairan (turbidity). TSS merupakan total masa bahan yang tersuspensi, baik bahan organik maupun nonorganik. Keberadaan TSS dan tingkat kekeruhan dapat diakibatkan dari aktivitas industri (point sources) maupun akibat dari erosi di daerah hulu (non-point sources). Peningkatan konsentrasi TSS dan tingkat kekeruhan di dalam perairan dapat mengakibatkan terganggunya ekosistem perairan. TSS akan menyerap energi panas matahari dan akan dapat meningkatkan suhu perairan, yang akhirnya dapat menurunkan oksigen terlarut. Proses fotosintesis juga dapat terganggu akibat dari berkurangnya penetrasi sinar matahari ke dalam kolom perairan. Demikian halnya dengan tingkat kekeruhan perairan akan berdampak terhadap terganggunya penetrasi cahaya kedalam kolom perairan. Terganggunya penetrasi cahaya matahari berakibat pada redahnya proses fotosintesis yang akhirnya menurunkan konsentrasi oksigen didalam kolom perairan.

Keberadaan sungai yang bermuara ke Teluk Benoa serta peningkatan aktivitas pelabuhan memiliki potensi yang cukup besar dalam meningkatkan konsentrasi TSS dan tingkat kekeruhan perairan. Hendrawan and Asai (2008) menunjukkan sebaran TSS permukaan di perairan Teluk Benoa melalui citra satelit, namun belum membahas secara mendalam karakteristik TSS secara vertikal maupun perubahannya akibat kondisi pasang surut. Pengetahuan karakteristik TSS maupun kekeruhan perairan yang lebih detail di perairan Teluk Benoa akan sangat membantu dalam peroses perencanaan pengelolaan wilayah perairan tersebut. Mengingat masih belum banyaknya penelitian yang dilakukan berhubungan dengan karakteristik TSS maupun tingkat kekeruhan di perairan Teluk Benoa, serta pentingnya parameter tersebut dalam menjaga kualitas ekosistem perairan, maka dalam penelitian ini dilakukan analisis terhadap karateristik TSS dan tingkat kekeruhan secara vertikal di perairan Teluk Benoa.

\section{Metode Penelitian}

\subsection{Data}

Stasiun pengambilan sampel TSS dan tingkat kekeruhan di perairan Teluk Benoa ditentukan sebanyak 10 stasiun. Sample air diambil disetiap stasiun dari permukaan sampai dasar perairan, dengan jarak setiap kedalaman 2 m. Sampel air pada setiap kedalaman diambil menggunakan vertikal water sampler. Sampel air yang telah diambil dimasukkan kedalam botol sample dan disimpan pada suhu $<4^{\circ} \mathrm{C}$ sebelum dilakukan pengujian TSS dan tingkat kekeruhan di laboratorium. Penyimpanan sampel pada suhu kurang dari $4^{\circ} \mathrm{C}$ dilakukan untuk meminimalkan dekomposisi mikrobiologikal terhadap padatan. Untuk mengurangi gangguan dalam analisis TSS maupun tingkat kekeruhan perairan, pada penelitian ini dilakukan pemisahan partikel besar yang mengapung pada sampel air.

\subsection{Analisis Data}

Sampel air yang telah diambil pada setiap stasiun, kemudian diuji dan dianalisis di laboratorium Fakultas
Kelautan dan Perikanan Universitas Udayana. Metode yang digunakan dalam pengujian dan analisa sampel TSS mengikuti prosedur Standar Nasional Indonesia (SNI) No. 06-6989.3-2004 tentang cara uji padatan tersuspensi total (Total Suspended Solid, TSS) secara gravimetri. TSS ditentukan dengan menyaring sampel air dengan kertas saring berukuran $2,5 \mu \mathrm{m}$, dan setelah itu di hitung selisih berat kertas saring sebelum dan setelah dilakukan penyaringan. Perhitungan TSS dapat ditentukan dengan persamaan (1) (BSN, 2004).

$$
\text { TSS per Liter }=\frac{(A-B) \times 1000}{\text { Volume Uji mL }}
$$

keterangan:
A: adalah berat kertas saring + residu kering (mg);
B: adalah berat kertas saring $(\mathrm{mg})$.

Untuk menjamin validitas pengukuran TSS, maka dalam penelitian ini juga dilakukan penjaminan terhadap mutu. Untuk penjaminan mutu, maka beberapa hal diperhitungkan yaitu:

- Menggunakan alat gelas bebas kontaminasi.

- Menggunakan alat ukur yang terkalibrasi.

- Melakukan analisis dalam jangka waktu yang tidak melampaui waktu simpan maksimum 24 jam

Sementara untuk menguji tingkat kekeruhan perairan, pada penelitian ini dilakukan dengan menggunakan alat tubidity-meter. Tingkat ketelitian turbidity-meter yang digunakan mencapai 0.01 .

\section{Hasil dan Pembahasan}

Pengambilan sampel air untuk pengukuran TSS dan tingkat kekeruhan perairan dilakukan pada tanggal 23 Juni 2015. Pengambilan sampel air dilakukan pada 10 stasiun untuk memperoleh karakteristik struktur vertikalnya (Gambar 1). Sampel air laut di perairan Teluk Benoa diambil pada saat kondisi pasang perbani.

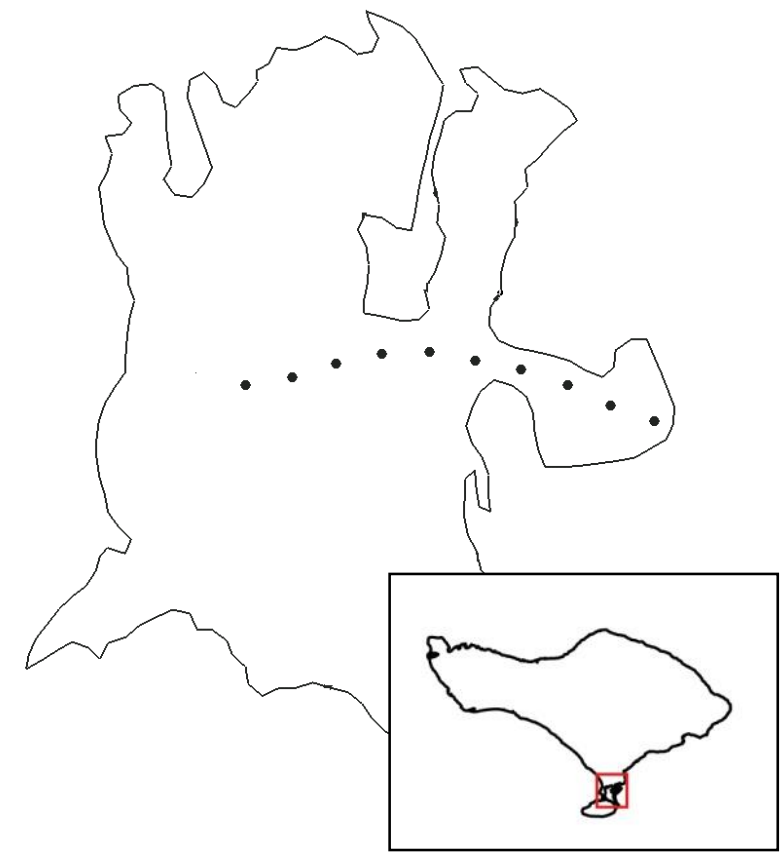

Gambar 1. Stasiun Pengamatan TSS secara vertikal, (•) 


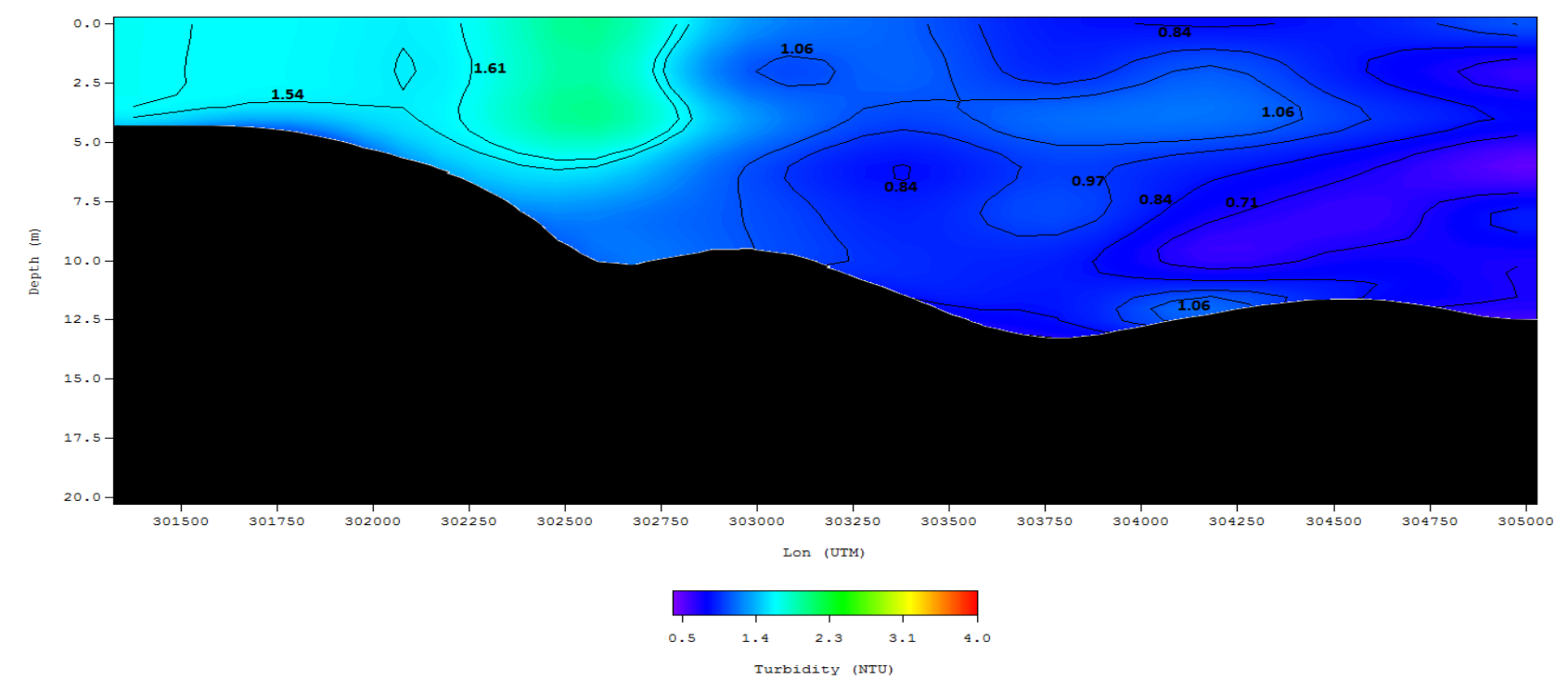

Gambar 2. Profil tampang melintang (cross section) tingkat kekeruhan perairan Teluk Benoa, kekeruhan dalam NTU

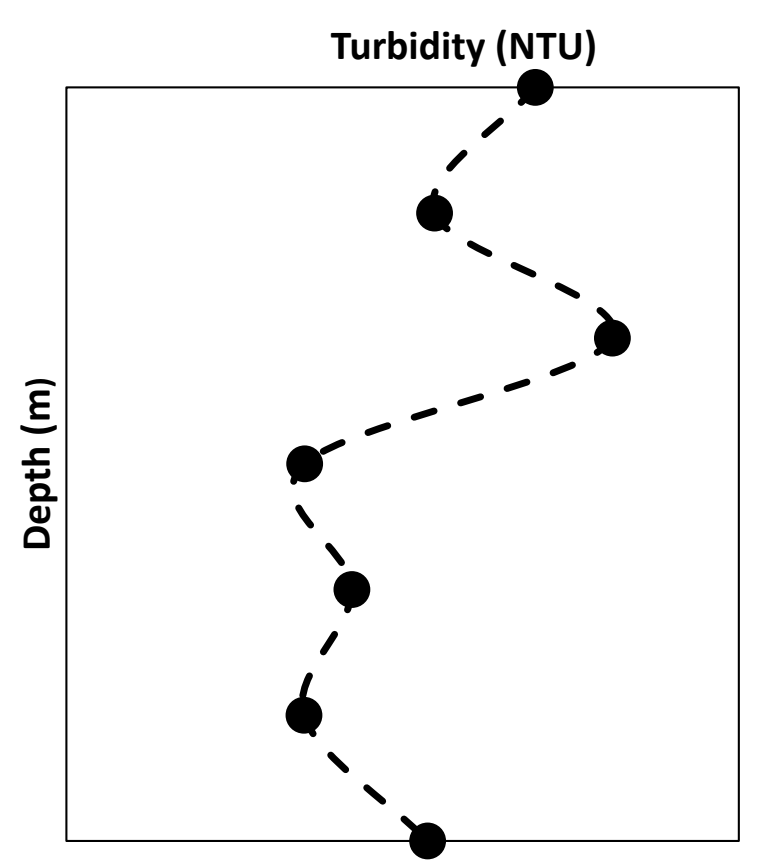

Gambar 3. Karakteristik tingkat kekeruhan secara vertikal di perairan Teluk Benoa, kekeruhan dalam NTU

Profil tampang melintang (cross section) kekeruhan perairan di perairan Teluk Benoa dapat dilihat pada (Gambar 2). Nilai rata-rata kekeruhan yang terlihat pada tampang melintang di stasiun pengamatan perairan Teluk Benoa adalah sebesar 1.03 NTU. Secara umum kekeruhan mengalami peningkatan di dalam perairan teluk yang mencapai 2 NTU di permukaan dan mulai menurun pada dasar perairan yang mencapai 1,54 NTU. Sedangkan pada mulut sampai luar teluk tingkat kekeruhannya mencapai 0,84 NTU pada permukaan, dan mulai meningkat pada kedalaman sekitar 2,5 - 5 m menjadi 1,06 NTU, kemudian kembali menurun di kedalaman sekitar 5 - $10 \mathrm{~m}$ yang mencapai 0,71 m, dan kembali meningkat di dasar perairan sekitar 1,06 NTU. Berdasarkan hasil tersebut dapat terlihat tingkat kekeruhan yang berada di dekat mulut teluk dan jalur pelayaran memiliki sebaran kekeruhan yang berubah di setiap kedalaman, sehingga ini membuktikan adanya proses pertukaran masa air yang lebih kompleks di setiap kedalamannya daripada di daerah di dalam teluk. Peningkatan kekeruhan perairan di mulut teluk dapat juga diakibatkan oleh perbedaan topography dasar perairan, yaitu perairan yang relatif dalam diluar teluk dan dangkal mulai mulut teluk.

Karakteristik rata-rata tingkat kekeruhan perairan secara vertikal dari permukaan sampai dasar perairan Teluk Benoa dapat dilihat pada (Gambar 3). Dari gambar tersebut terlihat bahwa tingkat kekeruhan perairan yang berbeda-beda pada setiap kedalaman, pada permukaan memiliki kekeruhan sekitar 1,2 NTU dan pada dasar perairan sekitar 1,0 NTU, dengan kekeruhan maksimum pada kedalaman 4 meter yaitu 1,3 NTU dan kekeruhan minimum pada kedalaman 10 meter yaitu 0,85 NTU. Hasil ini menunjukkan rata-rata tingkat kekeruhan di perairan mulai meningkat secara signifikan pada kedalaman $3 \mathrm{~m}$ dan turun kembali pada kedalaman $5 \mathrm{~m}$ dan mencapai dasar perubahannya tidak begitu signifikan.

Profil tampang melintang (cross section) TSS di perairan Teluk Benoa dapat dilihat pada (Gambar 4). Nilai rata-rata TSS secara vertikal di stasiun pengamatan perairan Teluk Benoa adalah sebesar 1168 mg/l. Secara umum, nilai TSS cenderung tinggi pada permukaan dan dasar perairan yaitu pada permukaan sekitar $1210 \mathrm{mg} / \mathrm{l}$ dan pada dasar perairan sekitar $1270 \mathrm{mg} / \mathrm{l}$, sedangkan di tengah-tengah kolom perairan (mid layer) nilai TSS cenderung rendah yaitu sekitar $963 \mathrm{mg} / \mathrm{l}$. Dari profil tampang melintang dapat terlihat nilai TSS yang tinggi di bagian dalam teluk, di bagian mid-layer (bagian tengah kolom perairan) pada kedalaman 2,5 meter yaitu sebesar $1931 \mathrm{mg} / \mathrm{l}$. Sementara di bagian luar teluk memiliki TSS yang relatif tinggi di bagian dasar perairan sebesar 1270 $\mathrm{mg} / \mathrm{l}$ dan dibagian permukaannya sebesar $1160 \mathrm{mg} / \mathrm{l}$. Hasil ini juga menguatkan bahwa di bagian permukaan air dimana terdapat aktifitas lalulintas kapal memiliki nilai TSS yang lebih tinggi daripada daerah mid layer perairan. Sedangkan pada dasar perairan juga memiliki nilai yang tinggi karena pada dasar perairan terdapat sedimen yang mengendap sehingga karena adanya arus bawah yang 


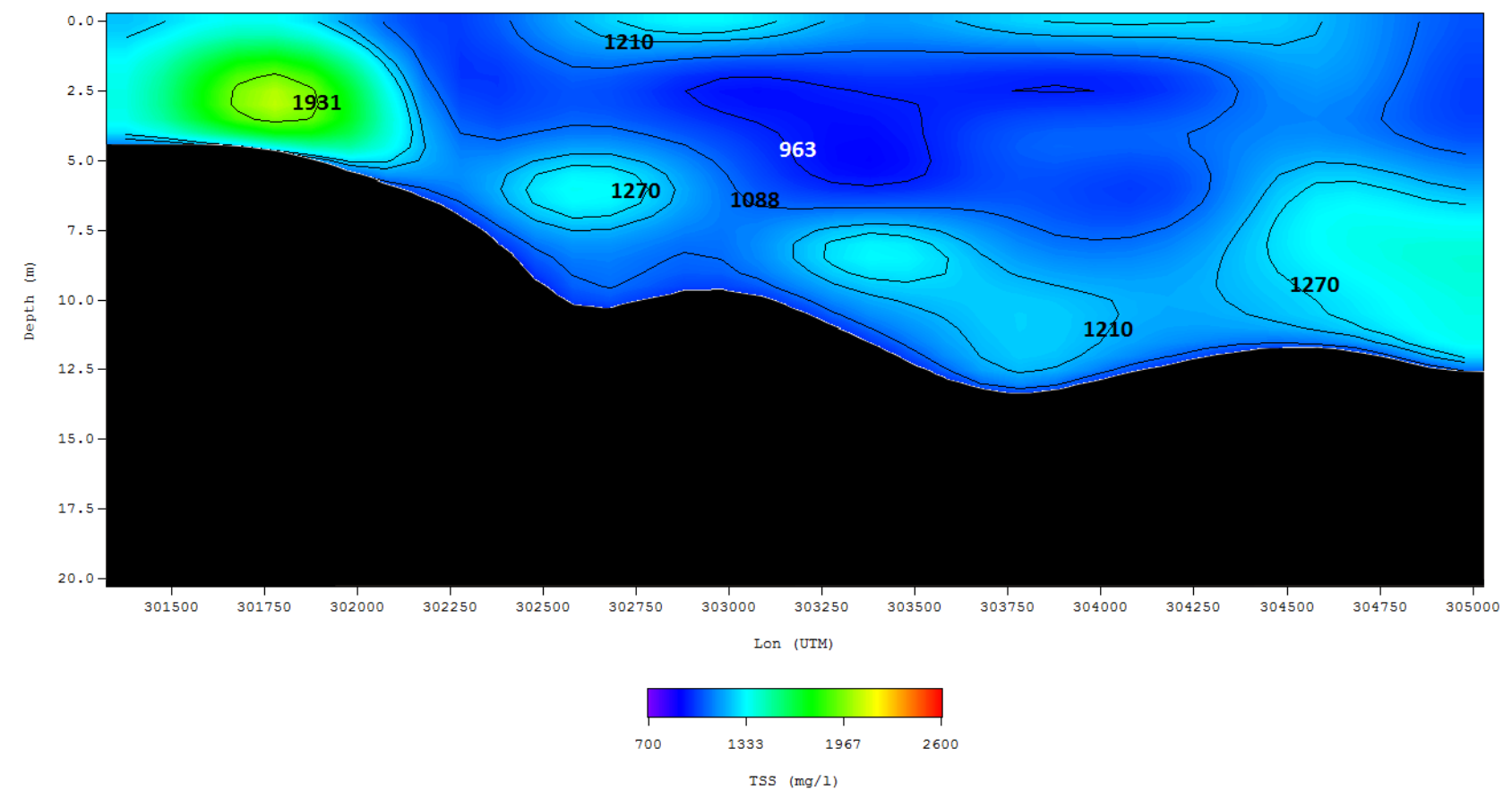

Gambar 4. Profil tampang melintang (cross section) tingkat kekeruhan perairan Teluk Benoa, kekeruhan dalam NTU

mengalir mengakibatkan sedimen tersebut terbawa oleh arus sehingga banyak partikel sedimen yang melayang di dasar perairan yang mengakibatkan kandungan TSS di dasar perairan juga tinggi.

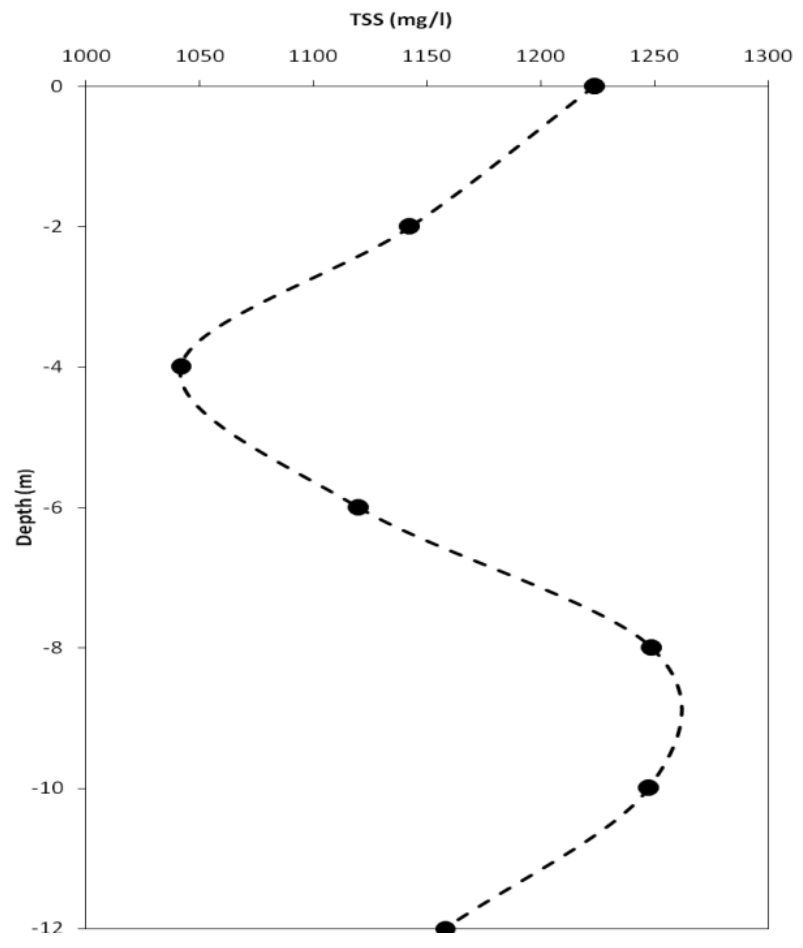

Gambar 5. Karakteristik TSS vertikal di perairan Teluk Benoa, TSS dalam satuan $(\mathrm{mg} / \mathrm{l})$

Karakteristik rata-rata TSS secara vertikal dari permukaan sampai dasar perairan Teluk Benoa dapat dilihat pada (Gambar 5). Dari gambar tersebut terlihat bahwa nilai TSS perairan yang berbeda-beda pada setiap kedalaman, pada permukaan memiliki nilai TSS sekitar $1224 \mathrm{mg} / \mathrm{l}$ dan pada dasar perairan sekitar $1158 \mathrm{mg} / \mathrm{l}$, dengan nilai TSS maksimum pada kedalaman 4 meter yaitu $1142 \mathrm{mg} / \mathrm{l}$ dan minimum pada kedalaman 8 sampai 10 meter yaitu sebesar $1250 \mathrm{mg} / \mathrm{l}$. Hasil ini menggambarkan adanya perbedaan nilai TSS yang signifikan pada permukaan, mid-layer, dan dasar perairan dimana pada permukaan nilai TSS relatif tinggi akibat dari adanya aktivitas pelayaran kemudian nilainya turun pada kedalaman 2 sampai $4 \mathrm{~m}$, dan meningkat kembali pada kedalaman $8 \mathrm{~m}$ akibat banayknya partikel sedimen yang melayang akibat adanya arus bawah.

Konsentrasi TSS dan tingkat kekeruhan di perairan Teluk Benoa, terutama dibagian mulut teluk sampai dengan bagian dalam teluk melalui alur pelayaran sangat dipengaruhi oleh aktivitas pelabuhan dan juga sirkulasi arus pasang surut. Arus pasang surut memiliki peran yang sangat signifikan dalam pergerakan material di perairan teluk (Awaji dkk, 1980; Hatayama dkk, 1996)). Peran arus residu di perairan Teluk Benoa memberikan kontribusi yang penting dalam pergerakan material di Teluk Benoa (Hendrawan dkk, 2005; Hendrawan dan Asai, 2014). Jika dilihat karakterisik TSS dan turbidity pada penelitian ini, terlihat secara jelas peranan arus di dasar laut yang mendorong material ke dalam teluk pada saat kondisi surut menuju pasang (Gambar 2; Gambar 4) yang menyebabkan tingginya TSS dan kekruhan di dasar perairan dan daerah dalam teluk. Akibat dari topography dasar laut yang semakin dangkal ke arah dalam teluk juga mengakibatkan meningkatnya arus vertikal sehingga material di dalam teluk terangkat ke permukaan.

\section{Simpulan}

Konsentrasi TSS memiliki nilai yang cukup tinggi di bagian permukaan perairan dan juga pada bagian dasar kolom perairan namun pada kedalaman 4 meter memiliki 
konsentrasi yang minimum. Konsentrasi TSS juga memiliki variasi terhadap jarak dari mulut teluk sampai pada bagian dalam teluk. Konsentrasi TSS pada bagian dalam teluk memiliki konsentrasi lebih tinggi dibandingkan pada bagian mulut teluk, terutama pada bagian permukaan perairan. Karakteristik yang sama juga terlihat pada kekeruhan perairan. Tingkat kekeruhan memiliki nilai yang lebih besar pada bagian dalam teluk dibandingkan pada bagian luar teluk.

Penelitian ini masih memiliki keterbatasan, mengingat data yang diambil masih sangat terbatas. Sehingga diperlukan penelitian lanjutan yang berupa pengambilan data yang lebih panjang (time series data) dan jumlah stasiun yang lebih banyak. Dengan penelitian lanjutan tersebut diharapkan akan dapat menunjukkan kondisi yang lebih komprehensif di perairan Teluk Benoa.

\section{Ucapan terimakasih}

Penulis mengucapkan terimakasih kepada LPPM Universitas Udayana yang telah memberikan dana penelitian melalui kontrak penelitian No. 39113/UN14.2/PNL.01.03.00/2015. Melalui kesempatan ini, penulis juga mengucapkan terimakasih kepada Fakultas Kelautan dan Perikanan Universitas Udayana yang telah mengijinkan menggunakan Laboratorium dalam analisis data

\section{Daftar Pustaka}

Awaji, T., Imasato, N., \& Kunishi, H. (1980). Tidal exchange through a strait: A numerical experiment using a simple model basin. Journal of Physical Oceanography, 10(10), 1499-1508.

BSN. (2004). Standar Nasional Indonesia (SNI) Air dan air limbah-Bagian 3: Cara uji padatan tersuspensi total (Total
Suspended Solid, TSS) secara gravimetri. Jakarta-Indonesia: Badan Standardisasi Nasional

Dishidros TNI AL. (2003). Peta Alur laut Kepulauan Indonesia: Lembar Bali. Jakarta-Indonesia: Dinas Hidro-Oseanografi, Tentara Nasional Indonesia Angkatan Laut.

Guan, X. (2009). Monitoring Lake Simcoe water quality using Landsat TM images. MS Thesis. University of Waterloo: waterloo-Canada.

Hatayama, T., Awaji, T., \& Akitomo, K. (1996). Tidal currents in the Indonesian Seas and their effect on transport and mixing. Journal of Geophysical Research: Oceans, 101(C5), 12353-12373.

Hendrawan, I. G., \& Asai, K. (2008). Study of Suspended Sediment Distribution Using Numerical Model and Satellite Data in Benoa Bay-Bali, Indonesia. International Journal of Remote Sensing and Earth Sciences, 5, 84-91.

Hendrawan, I. G., \& Asai, K. (2014). Numerical study on tidal currents and seawater exchange in the Benoa Bay, Bali, Indonesia. Acta Oceanologica Sinica, 33(3), 90-100.

Hendrawan, I. G., Nuarsa, I. W., Sandi, I. W. S., Koropitan, A. F., \& Sugimori, Y. (2005). Numerical Calculation for the Residual Tidal Current in Benoa Bay-Bali Island. International Journal of Remote Sensing and Earth Sciences, 2, 86-93.

Karr, J. R., \& Dudley, D. R. (1981). Ecological perspective on water quality goals. Environmental management, 5(1), 55-68.

Kemenhut. (1993). Keputusan Menteri Kehutanan RI Nomor 544/Kpts-II/93, tentang penetapan Taman wisata alam prapat Benoa sebagai TAHURA Ngurah Rai. JakartaIndonesia: Kementerian Kehutanan Republik Indonesia.

Wiyanto, D. B., \& Faiqoh, E. (2015). Analisis vegetasi dan struktur komunitas Mangrove Di Teluk Benoa, Bali. Journal of Marine and Aquatic Sciences, 1(1), 1-7.

(C) 2016 by the authors; licensee Udayana University, Indonesia. This article is an open access article distributed under the terms and conditions of the Creative Commons Attribution license (http://creativecommons.org/licenses/by/3.0/). 